\title{
KORELASI ASUPAN VITAMIN B KOMPLEKS DENGAN GEJALA KLINIS PENDERITA SKIZOFRENIA DI RS ERNALDI BAHAR TAHUN 2018
}

\section{Correlation of Vitamin B Complex Intake with the Severity of the Symptoms of Schizophrenic Patient at Ernaldi Bahar Hospital in 2018}

\author{
Mertien Sa'pang ${ }^{1 *}$, Miftahull Hassana ${ }^{1}$, Nadiyah ${ }^{1}$ \\ ${ }^{1}$ Program Studi Gizi, Fakultas IImu-IImu Kesehatan, Universitas Esa Unggul \\ JI. Arjuna Utara No.9 Duri Kepa, Kec. Kebon Jeruk, Jakarta Barat, DKI Jakarta, Indonesia \\ *e-mail: mertien.sapang@esaunggul.ac.id
}

Submitted: January $8^{\text {th }}, 2020$, revised: February $11^{\text {th }}, 2020$, approved: May $11^{\text {th }}, 2020$

\begin{abstract}
Background. People with schizophrenia are at risk of dying twice as high as people in general. Positive and Negative Syndrome Scale (PANSS) is the tool to measure the severity of the symptoms. Patients rarely show improvement in symptoms despite treatment. Therefore, other factors are needed, such as nutritional factors, through nutrient intake that can help improve symptoms in people with schizophrenia. One of the nutrients that play a role in mental health is vitamin B complex, which includes vitamin B6, B9, and B12. Objective. To determine the relationship between vitamin $B$ complex intake and the severity of the symptoms of schizophrenic patients. Method. The study is a descriptive quantitative observational study with a cross-sectional approach. The population in this study were all of 63 schizophrenic patients at the Ernaldi Bahar Hospital in South Sumatra Province. Data were analyzed using the Spearman correlation. Results. The majority of respondents have adequate vitamin $B 6$ and $B 9$ intake ( $\geq 77 \% R D A)$, yet inadequate B12 intake ( $\leq 77 \%$ RDA). The average PANSS score of respondents was 71.35 (min$\max =42-129)$. The result of this study showed that the PANSS score has a significant negative correlation $(p<0.05)$ with dietary intake of B6 and B9 with a correlation coefficient of $r=-0.421$; $r=-0.366$, respectively. Conclusion. The severity of the symptoms of schizophrenic patient have a negative correlation with dietary intake of B6 and B9 vitamin, but not in dietary intake of B12 vitamin. Further study needed to assess the effect of vitamin B complex on the severity of the symptoms of schizophrenic patients.
\end{abstract}

Keywords: schizophrenia, vitamin B6, vitamin B9, vitamin B12

\begin{abstract}
ABSTRAK
Latar belakang. Penderita skizofrenia berisiko mengalami kematian dua kali lebih tinggi dibandingkan masyarakat pada umumnya. Positive and Negative Syndrome Scale (PANSS) merupakan salah satu instrumen untuk mengukur gejala pada pasien skizofrenia. Pasien jarang menunjukkan perbaikan gejala meski telah menjalani pengobatan. Dibutuhkan faktor lain seperti faktor gizi melalui asupan zat gizi yang dapat membantu memperbaiki gejala pada penderita skizofrenia. Salah satu asupan zat gizi yang berperan dalam kesehatan mental adalah vitamin B kompleks meliputi vitamin B6, B9, dan B12. Tujuan. Penelitian ini bertujuan untuk mengetahui hubungan antara asupan vitamin $B$ kompleks dengan gejala klinis pada penderita skizofrenia menggunakan skor PANSS di Rumah Sakit Ernaldi Bahar, Provinsi Sumatera Selatan. Metode. Penelitian kuantitatif observasional yang bersifat deskriptif dengan pendekatan cross-sectional. Populasi dalam penelitian ini adalah seluruh pasien skizofrenia yang dirawat inap di Rumah Sakit Ernaldi Bahar dengan sampel berjumlah 63 responden. Analisis data menggunakan korelasi Spearman. Hasil. Sebagian besar responden mengonsumsi vitamin B6 dan B9 $\geq 77$ persen dari kebutuhan dan 49,2 persen responden mengonsumsi vitamin B12 $<77$ persen dari kebutuhan. Hasil penilaian skor total PANSS responden menunjukkan nilai rata-rata 71,35 dengan skor
\end{abstract}


terendah adalah 42 dan tertinggi adalah 129. Penelitian ini menunjukkan bahwa skor PANSS secara signifikan $(p<0,05)$ berkorelasi negatif dengan asupan vitamin B6 dan B9 dengan koefisien korelasi $r=-0,421 ; r=-0,366$. Kesimpulan. Gejala klinis pasien skizofrenia menunjukkan korelasi negatif dengan asupan vitamin B6 dan B9, namun tidak menunjukkan korelasi dengan asupan vitamin B12. Penelitian lebih lanjut dibutuhkan untuk menilai pengaruh vitamin B kompleks terhadap gejala klinis pasien skizofrenia.

Kata kunci: skizofrenia, vitamin B6, vitamin B9, vitamin B12

\section{PENDAHULUAN}

Menurut data World Health Organization (WHO) pada tahun 2017, sekitar 21 juta orang di seluruh dunia menderita skizofrenia. ${ }^{1}$ Menurut data Riset Kesehatan Dasar (2013), di Indonesia terdapat 1.728 orang menderita gangguan skizofrenia. Sumatera Selatan memiliki prevalensi skizofrenia lebih tinggi dibandingkan dengan lima provinsi lainnya di Sumatera sebesar 1,1 per 1000 penduduk dan menempati urutan tertinggi kelima di seluruh provinsi di Indonesia pada tahun $2007 .^{2}$

Tingkat kematian orang dengan skizofrenia dua kali lebih tinggi dibandingkan populasi umum. ${ }^{3}$ Bunuh diri adalah penyebab umum kematian pada penderita skizofrenia. ${ }^{4}$ Tingkat bunuh diri pada pasien skizofrenia diperkirakan antara 4 hingga 10 persen. ${ }^{5} \mathrm{Hal}$ ini dikarenakan skizofrenia mencakup serangkaian gejala yang sulit terkontrol, meliputi gejala positif (halusinasi, delusi, paranoid) dan gejala negatif (kurangnya motivasi, penarikan diri secara sosial, respon emosional menumpul).6,7 Meski pasien mengalami remisi gejala positif dalam beberapa bulan pertama pengobatan, namun hasil jangka panjangnya buruk karena 80 persen pasien mengalami kekambuhan dalam 5 tahun. Selain itu, gejala negatif sebagian besar tidak responsif terhadap pengobatan antipsikotik. ${ }^{8}$

Salah satu instrumen penilaian gejala pada pasien skizofrenia adalah Positive and Negative Syndrome Scale (PANSS) yang merupakan instrumen penilaian paling penting dalam penelitian skizofrenia dan telah divalidasi dalam beberapa bahasa. Instrumen ini dibagi ke dalam tiga subskala yaitu gejala positif, gejala negatif, dan psikopatologi umum serta terdapat tiga butir tambahan untuk menilai adanya risiko agresi. ${ }^{9,10}$

Beberapa faktor yang memengaruhi gejala dan perkembangan gangguan skizofrenia meliputi faktor biokimia, genetik, gizi, obatobatan terlarang, infeksi maternal, dan faktor lingkungan. ${ }^{11-13} \mathrm{Di}$ antara faktor tersebut, asupan zat gizi memiliki peran dalam memperbaiki gejala dan perkembangan gangguan meskipun bukan etiologi utama. Salah satu asupan zat gizi yang memiliki efek menguntungkan pada kesehatan mental adalah vitamin B kompleks (B6, B9, dan B12). ${ }^{14}$

Vitamin B6, B9, dan B12 berperan penting dalam pengembangan, pemeliharaan, dan fungsi otak. Salah satunya adalah peran vital pada donasi kelompok metil. Kekurangan vitamin B6, B9, dan B12 dapat menyebabkan peningkatan homosistein. Kadar homosistein yang tinggi telah dilaporkan terkait dengan gejala negatif skizofrenia. ${ }^{15,16}$

Berdasarkan uraian tersebut dan masih terbatasnya penelitian di Indonesia yang membahas tentang hubungan antara asupan zat gizi dan gejala klinis penderita skizofrenia, maka penulis tertarik untuk melakukan penelitian tentang hubungan antara asupan vitamin B kompleks (B6, B9, B12) dan gejala klinis penderita skizofrenia di Rumah Sakit Ernaldi Bahar, Provinsi Sumatera Selatan.

\section{METODE}

Penelitian ini dilakukan di Rumah Sakit Ernaldi Bahar, Provinsi Sumatera Selatan pada bulan Agustus 2018. Populasi dalam penelitian 
ini adalah seluruh pasien yang terdiagnosis skizofrenia di Rumah Sakit Ernaldi Bahar, Provinsi Sumatera Selatan pada bulan Agustus 2018. Responden berjumlah 63 pasien yang ditentukan secara purposive sampling. Kriteria inklusi adalah pasien skizofrenia yang menjalani rawat inap dan bersedia menjadi responden penelitian. Sedangkan kriteria eksklusi adalah pasien skizofrenia yang terpasang nasogastric tube dan pasien yang pulang paksa atau meninggal dunia sebelum data responden dikumpulkan secara lengkap.

Variabel dependen dalam penelitian ini adalah gejala klinis penderita skizofrenia yang dinilai menggunakan instrumen PANSS versi Bahasa Indonesia. Penilaian skor dilakukan oleh perawat terlatih. Uji reliabilitas, uji validitas, dan uji sensitivitas PANSS telah dilakukan oleh A. Kusumawardhani dan tim dari Fakultas Kedokteran Universitas Indonesia terhadap pasien skizofrenia di Indonesia pada tahun 1994. ${ }^{17-19}$ Derajat klinis pasien skizofrenia dinilai menggunakan metode PANSS yang terdiri dari 33 yaitu 7 butir skala positif, 7 butir skala negatif, 16 butir psikopatologi umum, dan terdapat 3 butir tambahan untuk menilai adanya risiko agresi. Penilaian PANSS dapat dilakukan oleh dokter atau perawat yang telah terlatih. Penilaian PANSS dalam penelitian ini dilakukan oleh perawat terlatih dan dinilai pada skala 1-7. Nilai 1 (tidak ada), 2 (minimal), 3 (ringan), 4 (sedang), 5 (agak berat), 6 (berat), 7 (sangat berat) sehingga rentang skala positif dan negatif dari 7-49 dan rentang skala psikopatologi umum dari $16-112 .^{9,19}$

Skala positif meliputi waham (delusi), kekacauan proses pikir, perilaku halusinasi, gaduh gelisah (excitement), waham kebesaran, kecurigaan/kejaran dan permusuhan. Skala negatif meliputi afek tumpul, penarikan emosional, kemiskinan rapport, penarikan diri dari hubungan sosial secara pasif/apatis, kesulitan dalam pemikiran abstrak, kurangnya spontanitas, dan arus pemikiran stereotipik. ${ }^{19}$ Skala psikopatologi umum dimasukkan sebagai tambahan penting untuk penilaian positif-negatif karena skala ini dapat berfungsi sebagai titik acuan atau ukuran kontrol untuk menafsirkan skor sindrom. Skala ini tidak diasumsikan secara statistik atau konseptual berbeda dari penilaian positif-negatif, tetapi hanya dapat digunakan sebagai tolok ukur dari gejala non spesifik tertentu untuk menilai keparahan manifestasi positif dan negatif yang berbeda. ${ }^{19}$

Variabel independen dalam penelitian ini adalah asupan vitamin B kompleks (B6, B9, dan B12) yang diperoleh melalui penimbangan makanan (food weighed) sebelum dan setelah makanan dikonsumsi oleh responden selama tiga hari secara acak dalam satu minggu (dua hari kerja, satu hari weekend). Pengambilan data konsumsi makanan tambahan dilakukan dengan wawancara. Hasil penilaian food weighed kemudian dikonversi ke dalam vitamin B6, vitamin B9, dan vitamin B12 dengan menggunakan Nutrition Composition of Food Singapore (Health Promotion Board, Singapore) dan software Nutrisurvey. Pelaksanaan penelitian ini telah disetujui secara etik oleh Komisi Etik Penelitian Universitas Esa Unggul dengan nomor: 0337-18.327/PKE-KEP/FINALEA/UEU/VIII/2018.

Analisis data meliputi analisis univariat dan analisis bivariat. Analisis univariat digunakan untuk mendeskripsikan gambaran responden dan tingkat kecukupan vitamin B6, B9, dan B12. Tingkat kecukupan vitamin B6, B8, dan B12 dikategorikan ke dalam dua kelompok dengan kategori kurang ( $<77 \%$ AKG) dan cukup $\left(\geq 77 \%\right.$ AKG). ${ }^{20}$ Sedangkan analisis bivariat dilakukan dengan uji korelasi Spearman untuk menganalisis hubungan antara asupan vitamin B6, B9, B12 dengan skor PANSS karena data tidak terdistribusi normal setelah dilakukan uji normalitas dengan Kolmogorov Smirnov. 


\section{HASIL}

Hasil wawancara karakteristik responden menunjukkan bahwa sebagian besar responden berjenis kelamin laki-laki $(68,3 \%)$ dengan ratarata usia responden adalah 36,49 tahun. Usia responden paling rendah adalah 20 tahun dan paling tinggi adalah 59 tahun. Sebagian besar responden yang dirawat adalah skizofrenia paranoid $(69,8 \%)$ dan merupakan pasien BPJS $(55,6 \%)$. Sebagian besar responden dirawat tanpa penyakit penyerta $(90,5 \%)$, telah cukup lama menjalani perawatan selama $\geq 12$ hari $(50,8 \%)$, dan memiliki status gizi normal $(58,7 \%)$ (Tabel 1).

Tabel 1. Karakteristik Responden

\begin{tabular}{|c|c|c|}
\hline Karakteristik & $\mathrm{n}$ & $\%$ \\
\hline \multicolumn{3}{|l|}{ Jenis kelamin } \\
\hline Laki-laki & 43 & 68,3 \\
\hline Perempuan & 20 & 31,7 \\
\hline \multicolumn{3}{|l|}{ Jenis skizofrenia } \\
\hline Skizofrenia paranoid & 44 & 69,8 \\
\hline Skizofrenia hebefrenik & 3 & 4,8 \\
\hline Skizofrenia tak terinci & 9 & 14,3 \\
\hline Skizofrenia yang tak tergolongkan & 7 & 11,1 \\
\hline \multicolumn{3}{|l|}{ Lama hari rawat } \\
\hline$<12$ hari & 31 & 49,2 \\
\hline$\geq 12$ hari & 32 & 50,8 \\
\hline \multicolumn{3}{|l|}{ Penyakit penyerta } \\
\hline Ada & 6 & 9,5 \\
\hline Tidak ada & 57 & 90,5 \\
\hline \multicolumn{3}{|l|}{ Status gizi } \\
\hline Underweight & 17 & 27 \\
\hline Normal & 37 & 58,7 \\
\hline Overweight & 9 & 14,3 \\
\hline \multicolumn{3}{|l|}{ Jenis pasien } \\
\hline Umum & 8 & 12,7 \\
\hline BPJS & 35 & 55,6 \\
\hline Jamsoskes & 13 & 20,6 \\
\hline Jaminan kesehatan nasional & 7 & 11,1 \\
\hline
\end{tabular}

Hasil pengukuran konsumsi responden menunjukkan bahwa rata-rata asupan vitamin
B6 adalah 2,18 mg, vitamin B9 adalah 343,13 $\mu \mathrm{g}$, dan vitamin B12 adalah 4,67 $\mu \mathrm{g}$ (Tabel 2). 
Tabel 2. Data Asupan Vitamin B6, B9, dan B12 Responden

\begin{tabular}{lc}
\hline Asupan & Mean $\pm S D$ \\
\hline Vitamin B6 $(\mathrm{mg})$ & $2,18 \pm 1,462$ \\
Vitamin B9 $(\mu \mathrm{g})$ & $343,13 \pm 74,645$ \\
Vitamin B12 $(\mu \mathrm{g})$ & $4,67 \pm 4,045$ \\
\hline
\end{tabular}

Tingkat kecukupan vitamin B6, B9, dan B12 responden berdasarkan Angka Kecukupan Gizi (AKG) yang dikategorikan ke dalam 2 kelompok dengan kategori kurang ( $<77 \%$ AKG) dan cukup ( $\geq 77 \%$ AKG). Seperti pada Tabel 3, didapatkan bahwa asupan vitamin B6 sebagian besar responden telah tergolong cukup $(90,5 \%)$, asupan vitamin B9 responden berada dalam kategori cukup $(61,9 \%)$, dan sebagian besar responden berada dalam tingkat kecukupan vitamin $B 12$ yang kurang $(50,8 \%)$.

Tabel 3. Data Tingkat Kecukupan Asupan Vitamin B6, B9, dan B12 Responden

\begin{tabular}{ccc}
\hline Tingkat Kecukupan & $\mathrm{n}$ & $\%$ \\
\hline Vitamin B6 & & \\
Kurang & 6 & 9,5 \\
Cukup & 57 & 90,5 \\
Vitamin B9 & & \\
Kurang & 24 & 38,1 \\
Cukup & 39 & 61,9 \\
Vitamin B12 & & \\
Kurang & 32 & 50,8 \\
Cukup & 31 & 49,2 \\
\hline
\end{tabular}

Pemeriksaan PANSS dilakukan oleh perawat terlatih. Hasil pemeriksaan tersebut menunjukkan bahwa rata-rata skor total PANSS responden adalah 71,35 . Hasil lebih lengkap tersaji dalam Tabel 4.

Tabel 4. Data Skor PANSS Responden

\begin{tabular}{lc}
\hline \multicolumn{1}{c}{ Skor PANSS } & Mean $\pm S D$ \\
\hline Positif & $15,21 \pm 5,268$ \\
Negatif & $15,32 \pm 6,555$ \\
Psikopatologi umum & $33,56 \pm 11,506$ \\
Risiko agresi & $7,27 \pm 3,249$ \\
Skor PANSS total & $71,35 \pm 24,025$ \\
\hline
\end{tabular}


Hasil uji hubungan antara asupan vitamin B6, B9, B12 dengan skor PANSS menunjukkan bahwa kedua variabel memiliki hubungan yang signifikan dengan nilai $p=0,001$ dan nilai koefisien korelasi ( $r$ ) sebesar $-0,421$ yang berpola negatif atau memiliki arah hubungan terbalik dan menunjukkan kekuatan hubungan yang sedang antara asupan vitamin B6 dan skor PANSS yang berarti bahwa semakin tinggi asupan vitamin B6 yang dikonsumsi maka semakin rendah skor PANSS. Selain itu, ditemukan bahwa secara signifikan terdapat hubungan antara asupan vitamin B9 dan skor PANSS dengan nilai $p=0,003$ dan nilai koefisien korelasi $(r)$ sebesar $-0,366$ yang berpola negatif atau memiliki arah hubungan terbalik dan menunjukkan kekuatan hubungan yang lemah. Hal ini berarti bahwa semakin tinggi asupan vitamin B9 yang dikonsumsi maka semakin rendah skor PANSS. Berdasarkan uji statistik antara vitamin B12 dan skor PANSS, tidak ditemukan hubungan yang signifikan antara kedua variabel tersebut dengan nilai $p=0,214$ dan nilai koefisien korelasi (r) sebesar -0,159 yang menunjukkan arah hubungan terbalik antara vitamin B12 dan skor PANSS.

Tabel 5. Hubungan Asupan Vitamin B6, B9, B12 dengan Skor PANSS

\begin{tabular}{lcc}
\hline \multicolumn{1}{c}{ Variabel } & Koefisien Korelasi $(r)$ & $p$ Value \\
\hline Asupan vitamin B6 & $-0,421^{*}$ & 0,001 \\
Asupan vitamin B9 & $-0,366^{*}$ & 0,003 \\
Asupan vitamin B12 & $-0,159$ & 0,214 \\
\hline
\end{tabular}

*signifikan pada $p<0,01$

\section{PEMBAHASAN}

\section{Karakteristik Responden}

Responden dalam penelitian ini adalah pasien skizofrenia yang dirawat inap di Rumah Sakit Ernaldi Bahar, Provinsi Sumatera Selatan. Dari hasil pengumpulan data ditemukan bahwa sebagian besar responden berjenis kelamin laki-laki. Hal ini sesuai dengan penelitian Fahrul et al, (2014) yang mendapatkan hasil bahwa sebagian besar pasien skizofrenia yang dirawat inap adalah laki-laki. ${ }^{21} \mathrm{Hal}$ tersebut juga sejalan dengan teori yang menyatakan kejadian skizofrenia 1,4 kali lebih tinggi terjadi pada lakilaki dibandingkan pada perempuan. ${ }^{22}$

Responden rata-rata berusia 36,5 tahun dengan usia terendah 20 tahun dan tertinggi adalah 59 tahun. Skizofrenia merupakan gangguan mental yang memengaruhi berbagai kelompok umur. ${ }^{23}$ Gejala skizofrenia biasanya dimulai antara usia 16 hingga 30 tahun dan sekitar 90 persen pasien dalam pengobatan skizofrenia adalah antara usia 15 sampai 55 tahun. ${ }^{24,25}$

Pada penelitian ini skizofrenia paranoid menempati jumlah terbanyak dalam jenis skizofrenia rawat inap. Hasil ini sesuai dengan penelitian oleh Jarut et al, (2013) yang menemukan sebagian besar pasien skizofrenia yang dirawat inap adalah pasien dengan skizofrenia paranoid. ${ }^{26}$ Skizofrenia paranoid merupakan jenis skizofrenia yang paling umum dijumpai secara epidemiologi, baik di Indonesia maupun di negara lain. ${ }^{27}$

Penelitian ini menunjukkan mayoritas responden merupakan peserta BPJS dirawat tanpa penyakit penyerta, dan menjalani rawat inap yang cukup lama yaitu $\geq 12$ hari. Hasil ini sejalan dengan penelitian Baeza et al, (2018) yang menyatakan bahwa pasien dengan skizofrenia lebih lama tinggal sebagai pasien rawat inap psikiatri daripada pasien dengan 
gangguan mental lainnya. ${ }^{28} \mathrm{Hal}$ ini diperkirakan sebagai gambaran kombinasi gejala akut yang kompleks dan sulit diobati serta adanya penarikan sosial yang menjadi karakteristik skizofrenia sehingga membutuhkan hari rawat yang cukup lama. Sebagian besar responden yaitu 58,7 persen memiliki status gizi normal. Hal ini sesuai dengan penelitian lain yang mendapati prevalensi status gizi normal pada pasien skizofrenia lebih tinggi dibandingkan dengan status gizi kurang dan status gizi lebih. ${ }^{29}$

\section{Asupan Vitamin B6, B9, dan B12}

Berdasarkan data yang diperoleh dari food weighed menunjukkan bahwa sebagian besar responden mengonsumsi makanan sumber vitamin B6 yang cukup bervariasi meliputi hati, ayam, telur, ikan, pisang, kentang, kacangkacangan, sayur-sayuran seperti bayam, wortel, kembang kol, dan lain-lain (hasil disajikan dalam jumlah asupan vitamin B6). Sehingga rata-rata responden dalam penelitian ini memiliki asupan vitamin B6 yang cukup.

Asupan vitamin B9 responden juga telah mencukupi angka kecukupan vitamin B9 yang dianjurkan. Asupan tersebut dapat terpenuhi karena dari hasil food weighed menunjukkan bahwa selain mengonsumsi makanan sumber vitamin B9 yang cukup beragam seperti serealia, sayur, kacang-kacangan, jeruk, susu, telur, hati, dan ikan, sejumlah responden juga mendapat extra feeding dari produk susu komersil yang memiliki kandungan vitamin B9 cukup tinggi (hasil disajikan dalam jumlah asupan vitamin B9).

Sebagian besar asupan vitamin B12 responden berada dalam kategori kurang. Hal ini dikarenakan sumber vitamin B12 dari asupan makanan tidak cukup bervariasi. Sebagian besar sumber vitamin B12 diperoleh dari lauk hewani seperti hati, ikan, telur, dan susu (hasil disajikan dalam jumlah asupan vitamin B12).

\section{Skor PANSS}

Berdasarkan hasil statistik, rata-rata skor total PANSS responden berada dalam rentang ringan (33-99). Skala positif, negatif, psikopatologi umum, dan risiko agresi juga masing-masing ditemukan berada dalam rentang ringan. Hasil ini dapat disebabkan karena responden rutin mengonsumsi obat dan jarang menyisakan makanan dari menu yang disediakan oleh rumah sakit.

\section{Hubungan Asupan Vitamin B6, B9, dan B12 dengan Skor PANSS}

Berdasarkan uji korelasi Spearman, didapatkan hasil bahwa terdapat hubungan yang signifikan antara asupan vitamin B6 dan skor PANSS dengan arah hubungan terbalik dan keeratan hubungan yang cukup kuat antar variabel. Hal ini menunjukkan bahwa semakin tinggi asupan vitamin B6 yang dikonsumsi maka semakin rendah skor PANSS. Hasil ini sejalan dengan meta analisis dari 18 uji klinis acak terkontrol yang menunjukkan bahwa suplementasi vitamin B6 yang dikombinasikan dengan vitamin lain memberikan efek positif yang signifikan yaitu menurunkan skor gejala dan membantu mengurangi gejala kejiwaan. ${ }^{8}$

Vitamin B6 dibutuhkan dalam sintesis 3 neurotransmiter penting meliputi serotonin, dopamin, dan asam $\gamma$-aminobutirat (GABA). Selain itu, vitamin B6 terlibat dalam proses degradasi homosistein baik melalui remetilasi homosistein menjadi metionin maupun transulfurasi membentuk sulfat dan taurin. Vitamin B6 juga diubah menjadi glutation, antioksidan penting yang mampu mencegah penurunan aktivitas glutamat pada reseptorreseptor $N$-methyl-D-aspartate (NMDA) yang berperan dalam mengendalikan kecepatan neurotransmiter di sinaps sehingga mampu mencegah timbulnya gejala positif dan gejala negatif pada penderita skizofrenia. ${ }^{29-34}$ 
Berdasarkan uji korelasi Spearman terdapat hubungan antara vitamin B9 dan skor PANSS dengan arah hubungan terbalik yang menunjukkan bahwa semakin tinggi asupan vitamin B9 maka semakin rendah skor PANSS. Hasil ini sejalan dengan penelitian Kulaksizoglu (2016) yang menyatakan bahwa folat memiliki hubungan yang signifikan dengan skor PANSS dari skala negatif. ${ }^{35}$ Folat dan vitamin B12 terlibat dalam proses remetilasi homosistein menjadi metionin. Kadar homosistein yang tinggi dilaporkan memiliki hubungan dengan gejala negatif pada skizofrenia. Semakin tinggi kadar homosistein maka semakin tinggi tingkat keparahan gejala negatif pada penderita skizofrenia berdasarkan skor PANSS. ${ }^{16,36}$

Pada penelitian ini tidak ditemukan hubungan yang signifikan antara vitamin B12 dengan skor PANSS. Hal ini bertentangan dengan hasil penelitian Kulaksizoglu (2016) yang menunjukkan adanya hubungan signifikan antara vitamin B12 dan skor PANSS walaupun korelasi yang didapatkan memiliki keeratan hubungan yang sangat lemah. ${ }^{36}$ Hasil ini dapat disebabkan karena sebagian besar responden berada dalam tingkat kecukupan vitamin B12 kurang yang dimungkinkan akibat dari makanan sumber vitamin B12 yang kurang beragam. Sebagian besar vitamin B12 diperoleh dari lauk hewani seperti hati, ikan, telur, dan susu. Bioavailabilitas vitamin B12 dari asupan makanan secara signifikan juga tergantung pada penyerapan gastrointestinal. ${ }^{37}$ Meskipun hasil yang didapatkan tidak berhubungan secara signifikan, uji korelasi antara vitamin B12 dan skor PANSS menunjukkan arah hubungan terbalik. Artinya semakin tinggi asupan vitamin B12 maka semakin rendah skor PANSS. Hal ini sesuai dengan hasil penelitian terdahulu yang menunjukkan bahwa semakin tinggi asupan vitamin B12 maka skor PANSS akan semakin menurun. ${ }^{35}$

\section{KESIMPULAN}

Terdapat hubungan yang signifikan antara asupan vitamin B6 dan B9 dengan skor PANSS. Namun tidak terdapat hubungan antara vitamin B12 dengan gejala klinis. Penelitian lebih lanjut perlu dilakukan untuk menilai efektivitas intervensi gizi melalui asupan vitamin B kompleks yang adekuat terutama B6 dan B9 terhadap gejala skizofrenia.

\section{SARAN}

Perlu dilakukan penelitian lebih lanjut terkait dengan asupan dan gejala klinis pada penderita skizofrenia di rumah sakit lain atau pada penderita skizofrenia rawat jalan dengan asupan yang lebih beragam. Selain itu, disarankan juga untuk mengevaluasi kadar serum vitamin B kompleks (B6, B9, dan B12) pada penderita skizofrenia dan membandingkannya dengan asupan dan gejala klinis.

\section{UCAPAN TERIMA KASIH}

Terima kasih disampaikan kepada semua pihak yang telah ikut membantu dalam pelaksanaan penelitian, termasuk semua responden dan keluarga besar RS Ernaldi Bahar, Provinsi Sumatera Selatan.

\section{DAFTAR PUSTAKA}

1. World Health Organization. Mental Disorders: Information for The Public. 2017. Diunduh dari: http://www.who.int/mediacentre/ factsheets/fs396/en/, tanggal 03 April 2018

2. Badan Penelitian dan Pengembangan Kesehatan, Kementerian Kesehatan Republik Indonesia. Riset Kesehatan Dasar (Riskesdas) 2013. Jakarta: Badan Penelitian dan Pengembangan Kesehatan, Kementerian Kesehatan Republik Indonesia; 2013.

3. Reininghaus U, Dutta R, Dazzan P, Doody GA, Fearon P, Lappin J, et al. Mortality in Schizophrenia and Other Psychoses: A 10- 
Year Follow-Up of The ÆEsop First-Episode Cohort. Schizophr Bull. 2015;41(3):664-73.

4. Ventriglio A, Gentile A, Bonfitto I, Stella E, Mari M, Steardo L, et al. Suicide in The Early Stage of Schizophrenia. Front Psychiatry. 2016;7(116):1-9

5. Teraishi T, Hori H, Sasayama D, Matsuo J, Ogawa S, Ishida I, et al. Relationship between Lifetime Suicide Attempts and Schizotypal Traits in Patients with Schizophrenia. PLoS One. 2014;9(9):1-6.

6. Arroll MA, Wilder L, Neil J. Nutritional Interventions for The Adjunctive Treatment of Schizophrenia: A Brief Review. Nutr J. 2014;13(91):1-9.

7. Patel KR, Cherian J, Gohil K, Atkinson D. Schizophrenia: Overview and Treatment Options. P T. 2014;39(9):638-45.

8. Firth J, Stubbs B, Sarris J, Rosenbaum S, Teasdale S, Berk M, et al. The Effects of Vitamin and Mineral Supplementation on Symptoms of Schizophrenia: A Systematic Review and Meta-Analysis. Psychol Med. 2017;47(9):1515-27.

9. Ambarwati WN. Keefektifan Cognitive Behavior Therapy (CBT) sebagai Terapi Tambahan Pasien Skizofrenia Kronis di Panti Rehabilitasi Budi Makarti Boyolali Tesis. Surakarta: Program Studi Dokter Spesialis Fakultas Kedokteran Universitas Sebelas Maret, 2009.

10. Higuchi $\mathrm{CH}$, Ortiz B, Berberian AA, Noto C, Cordeiro Q, Belangero SI, et al. Factor Structure of The Positive and Negative Syndrome Scale (PANSS) in Brazil: Convergent Validation of The Brazilian Version. Rev Bras Psiquiatr. 2014;36(4):3369.

11. Beilharz JE, Maniam J, Morris MJ. DietInduced Cognitive Deficits: The Role of Fat and Sugar, Potential Mechanisms and Nutritional Interventions. Nutrients. 2015;7(8):6719-38.

12. Helgadóttir B, Forsell Y, Ekblom Ö. Physical Activity Patterns of People Affected by Depressive and Anxiety Disorders as Measured by Accelerometers: A CrossSectional Study. PLoS One. 2015;10(1):110.

13. Mahan L, Kathleen, Raymond JL. Krause's Food and The Nutrition Care Process. $14^{\text {th }}$ ed. Canada: Elsevier Inc; 2017.

14. Lim SY, Kim EJ, Kim A, Lee HJ, Choi HJ, Yang SJ. Nutritional Factors Affecting Mental Health. Clin Nutr Res. 2016;5(3):143.

15. Mitchell ES, Conus N, Kaput JB. Vitamin Polymorphisms and Behavior: Evidence of Associations with Neurodevelopment, Depression, Schizophrenia, Bipolar Disorder and Cognitive Decline. Neurosci Biobehav Rev. 2014;47:307-20. http://dx.doi. org/10.1016/j.neubiorev.2014.08.006

16. Ramachandran $P$, Thirunavakarasu $P$. Vitamins in Schizophrenia: A Literature Review. AP J Psychol Med. 2012;13(2):749.

17. Salam R, Budiman R, Bastaman TK, Yuniar S, Damping C, Kusumawardhani A. Pedoman Definisi PANSS (Positive and Negative Symptoms Scale). Jakarta: FK Universitas Indonesia; 1994.

18. Yulianti Y. Cetak Biru Pelayanan Pasien di Rumah Sakit Jiwa Provinsi Jawa Barat Tahun 2014. J Adm Rumah Sakit Indones. 2014;1(2):5-6.

19. Lestari ET. Perbedaan Skor PANSS, Indeks Massa Tubuh Pada Laki-Laki dengan Skizofrenia yang Mendapat Terapi Olanzapin dan Risperidon di Rumah Sakit Jiwa Prof. Dr. Muhammd Ildrem. Tesis. Medan: Program Pendidikan Dokter Spesialis I Psikiatri Fakultas Kedokteran Universitas Sumatera Utara, 2018. 
20. Gibson R. Principle of Nutritional Assessment. 2nd ed. Oxford University Press; 2005.

21. Fahrul, Mukaddas A, Faustine I. 2 Prodi Farmasi, untad Lab. Farmakologi dan Farmasi Klinik, Prodi Farmasi, Untad 1. Online J Nat Sci. 2014;3(1):40-6.

22. Seeman MV. Women and Schizophrenia: New Findings. Neuropsychiatry. 2013;3(4):42331.

23. Jeste DV, Maglione JE. Treating Older Adults with Schizophrenia: Challenges and Opportunities. Schizophr Bull. 2013;39(5):966-8.

24. Wenzel A. The SAGE Encyclopedia of Abnormal and Clinical Psychology. California: SAGE Publications Inc; 2017.

25. Wijayanti A, Puspitosari WA. Hubungan Onset Usia dengan Kualitas Hidup Penderita Skizofrenia di Wilayah Kerja Puskesmas Kasihan II Bantul Yogyakarta. Mutiara Medika. 2014;14(1):39-45.

26. Jarut YM, Fatimawali, Wiyono WI. Tinjauan Penggunaan Antipsikotik Pada Pengobatan Skizofrenia Di Rumah Sakit Prof. Dr. V. L. Ratumbuysang Manado Periode Januari 2013-Maret 2013. J IIm Farm. 2013;2 (03):54-7.

27. Muhyi A. Prevalensi Penderita Skizofrenia Paranoid Dengan Gejala Depresi Di RSJ Dr. Soeharto Heerdjan Jakarta Tahun 2010. Skripsi.Jakarta: Program Studi Pendidikan Dokter Fakultas Kedokteran dan IImu Kesehatan Universitas Islam Negeri Syarif Hidayatullah, 2011.

28. Baeza FLC, Da Rocha NS, Fleck MP. Predictors of Stay in An Acute Psychiatric
Inpatient Facility in A General Hospital: A Prospective Study. Rev Bras Psiquiatr. 2018;40(1):89-96.

29. Maisyarah TA, Nugraha GI, Lidyana L. Nutritional Status of Schizophrenic Patients at Department of Psychiatry in Dr. Hasan Sadikin General Hospital. Althea Medical Journal. 2014;1(1):40-7.

30. Stahl SM. Stahls Essential Psychopharmacology. $3^{\text {rd }}$ ed. Cambridge: Cambridge University Press; 2008.

31. Moustafa AA, Hewedi DH, Eissa AM, Frydecka D, Misiak B. Homocysteine levels in Schizophrenia and Affective Disorders Focus on Cognition. Front Behav Neurosci. 2014;8(10):1-10.

32. Mann Jim, Truswell AS. Buku Ajar Ilmu Gizi. Jakarta: EGC; 2014.

33. Almatsier S. Prinsip Dasar IImu Gizi. Jakarta: PT Gramedia Pustaka Umum; 2009.

34. Walsh W. Nutrient Power. Jakarta: PT Jejak Benang Emas; 2015.

35. Kulaksizoglu B, Kulaksizoglu S. Correlation of Metabolic Syndrome with Serum BDNF, Vitamin B12 And Folate in Schizophrenic Patients. Res J Pharm Biol Chem Sci. 2016;7(6):3142.

36. Misiak B, Frydecka D, Slezak R, Piotrowski P, Kiejna A. Elevated Homocysteine Level in First-Episode Schizophrenia Patients - The Relevance of Family History of Schizophrenia and Lifetime Diagnosis of Cannabis Abuse. Metab Brain Dis. 2014;29(3):661-70.

37. Watanabe F. Vitamin B12 Sources and Bioavailability. Exp Biol Med. 2007;232(10):126674. 